\title{
PENGARUH PELATIHAN TERHADAP PRESTASI KERJA PEGAWAI (STUDI KASUS CV. AYOEB BROTHERS DI PALEMBANG)
}

\author{
Tri Darmawati*)
}

\begin{abstract}
Abstrak
Penelitian ini bertujuan untuk mengkaji pengaruh pelatihan terhadap prestasi kerja pegawai pada CV. Ayoeb Brothers di Palembang. Populasi dalam penelitian ini adalah seluruh pegawai yang bekerja di CV. Ayoeb Brothers di Palembang sebanyak 34 orang, sedangkan sampel yang digunakan dalam penelitian ini berjumlah 34 Responden. Variabel yang digunakan adalah pelatihan dan prestasi kerja. Teknik analisis data yang digunakan adalah analisisi regresi linear sederhana, koefisien korelasi sederhana, koefisien determinasi dan uji t dengan menggunakan bantuan aplikasi statistik SPSS (Statistical Product and Service Solution).

Hasil penelitian menunjukkan bahwa diperoleh persamaan regresi linear sederhana yaitu $Y=31,624+0,258 X$. Hasil koefisien korelasi sederhana $(r)$ adalah 0,402 . Koefisien determinasi sebesar $16,2 \%$. Untuk uji hipotesis nilai t-hitung > t-tabel, 3,007>2,037. Jadi Ho ditolak Ha diterima, ada pengaruh positif yang signifikan pelatihan terhadap prestasi kerja pegawai CV. Ayoeb Brothers.
\end{abstract}

Kata Kunci : Pelatihan, dan Prestasi Kerja pegawai

\section{A. Pendahuluan}

Semakin berkembangnya ilmu pengetahuan dan teknologi, terutama di era globalisasi saat ini maka suatu intansi atau perusahaan dituntut untuk mampu mengikuti perkembangan oleh karena itu suatu intansi atau perusahaan membutuhkan sumber daya manusia yang unggul, baik dalam kapasitas penguasaan ilmu pengetahuan dan teknologi maupun sikap mental. Untuk itu perusahaan hendaknya selalu berusaha untuk mengembangkan dan meningkatkan kemampuan pegawainya, karena kemampuan pegawai merupakan salah satu faktor pendukung keberhasilan perusahaan dalam menjaga berkelangsungan hidup perusahaan. Pegawai dapat mengembangkan keterampilannya dalam menjalankan segala aktifitas pekerjaannya maka salah satu cara yang harus dilaksanakan oleh perusahaan adalah dengan memberikan pelatihan.

Pelatihan merupakan salah satu cara menghasilkan tenaga kerja yang terdidik serta profesional. Selain itu pelatihan juga diharapkan dapat meningkatkan kepribadian, pengetahuan, dan kemampuan pegawai sesuai dengan jabatannya, oleh sebab itu pelatihan merupakan salah satu aspek yang perlu ditangani secara terencana dan berkelanjutan. Program pelatihan merupakan aspek penting bagi para institusi untuk menciptakan tenaga yang ahli dan terampil karena pelatihan diharapkan dapat memberikan tambahan ilmu pengetahuan serta keahlian para pegawai di institusi tempat pegawai bekerja, adanya penanganan secara terencana dimaksudkan agar pelatihan tersebut dilakukan sesuai dengan jadwal dan kebutuhan institusi dalam meningkatkan kualitas pegawai, sedangkan berkelanjutan dimaksudkan agar pelatihan kerja tersebut dilaksanakan secara kontinyu artinya tidak terputus dan berkesinambungan. Jika pelatihan sudah dilakukan secara teratur maka sudah dapat dipastikan bahwa dengan pelaksanaan pelatihan kerja tersebut dapat menghasilkan tenaga-tenaga kerja terampil yang sesuai dengan keahliannya.

Hal tersebut di atas relevan dengan tujuan pelatihan yaitu agar

*) Dosen Tetap Fakultas Ekonomi UPGRI Palembang 
masing-masing peserta pelatihan dapat melaksanakan pekerjaan secara efektif serta memudahkan dalam mengerjakan tugas pekerjaannya. Untuk itu maka materi yang diberikan dalam pelatihan biasanya berkaitan dengan teori-teori yang berhubungan dengan tugas dan pekerjaan yang ada pada lembaga tempat pegawai bekerja. Materi teori-teori tersebut diberikan untuk meningkatkan pengetahuan pegawai terutama pada pengetahuan yang berhubungan dengan pekerjaan sehingga pegawai mempunyai keterampilan dan wawasan yang luas, sehingga profesional kerja pegawai dapat ditingkatkan.

CV. Ayoeb Brothers tentunya memerlukan dan mengharapkan setiap pegawai ahli dan profesional dalam menjalankan tugasnya, maka perlu diselenggarakan pelatihan agar pegawainya dapat berdaya guna dan berhasil guna di dalam mengemban tugas dan pekerjaan. Berikut ini beberapa pendapat berbagai para ahli mengenai pelatihan:

a. Menurut Notoatmodjo (2000:25) menyatakan bahwa pelatihan adalah upaya untuk mengembangkan sumber daya manusia, terutama mengembangkan kemampuan intelektual dan keperibadian manusia. Pelatihan didalam suatu organisasi atau badan usaha adalah suatu proses pengembangan kemampuan kearah yang diinginkan oleh organisasi atau badan usaha yang bersangkutan yang bertujuan untuk meningkatkan kemampuan atau keterampilan khusus seseorang atau sekelompok orang.

b. Menurut Simamora dalam Gomes (2003:197) menjelaskan bahwa pelatihan diarahkan untuk pegawai mengerjakan kepegawaian mereka saat ini secara lebih baik. Pelatihan mempunyai fokus yang agak sempit dan harus memberikan manfaat organisasi secara tepat cepat.

c. Menurut Sihotang (2007:157) mengemukakan bahwa pelatihan adalah setiap kegiatan untuk memperbaiki performasi pekerja pada suatu pekerjaan tertentu yang merupakan tanggung jawabnya.

d. Menurut Flippo dalam Sedarmayanti (2007:164) menyatakan bahwa pelatihan merupakan proses membantu pegawai dalam memperoleh efektivitas pekerjaan sekarang atau yang akan datang melalui pengembangan kebiasaan pikiran dan tindakan, kecakapan, pengetahuan, dan sikap.

Menurut Hasibuan (2002:83) Perbedaan pendidikan dan pelatihan mencakup hal-hal sebagai berikut:

1. Pendidikan

a. Peserta pendidikan adalah pegawai manajerial pendidikan ditujukan untuk melakukan proses memberikan ilmu pengetahuan kepada pegawai manajerial, agar pegawai manajerial tersebut mendapatkan ilmu pengetahuan yang luas, sehingga pegawai manajerial tersebut dapat melaksanakan pekerjaannya sesuai dengan pengetahuan manajemennya.

b. Tujuan pendidikan adalah menciptakan manajerial skill yaitu untuk menciptakan pemimpin yang mempunyai ilmu pengetahuan yang luas dan kecakapannya dalam memimpin bawahannya.

c. Metode yang digunakan adalah metode pendidikan

Metode yang digunakan dalam pendidikan adalah metode yang memberikan pengetahuan teoritis 
dan konseptual yang di tujukan untuk membekali pegawai agar pegawai dapat menguasai teori maupun konsep dalam merumuskan pekerjaan yang dilakukannya.

d. Waktu yang digunakan dalam pendidikan bersifat jangka panjang.

Dalam program pendidikan waktu yang diperlukan cukup lama untuk mempelajari teori dan konsep bagi pegawai sehingga pegawai memperoleh pengetahuan yang luas yang berkaitan dengan pekerjaan.

e. Biaya yang dibutuhkan relatif besar

Dalam pendidikan waktu yang diperlukan bersifat jangka panjang dan pendidikan dilakukan pada jenjang formil sehingga biaya yang dibutuhkan relatif besar.

f. Tempat yang biasanya digunakan di dalam lokal/kelas

Tempat yang digunakan dalam pendidikan adalah didalam lokal atau kelas atau ruangan yang telah tersusun dan cukup nyaman bagi para peserta yang berasal dari kalangan intelektual.

2. Pelatihan

a. Peserta pelatihan adalah pegawai operasional

Peserta pelatihan merupakan pegawai menengah kebawah yaitu pegawai yang melaksanakan tugas operasional dilapangan. Tujuan dari pelatihan adalah menciptakan tenaga technical skill yaitu untuk menciptakan tenaga yang ahli dalam bidang teknik yang berkaitan dengan tugas operasional dilapangan.

b. Metode yang digunakan adalah metode pelatihan
Metode yang digunakan adalah metode pelatihan yaitu praktek di lapangan dan pelatihan tersebut dilakukan dengan mengarahkan pegawai untuk praktek langsung terhadap pekerjaan.

c. Waktu yang dibutuhkan jangka pendek

Dalam pelatihan waktu yang dibutuhkan tidak terlalu lama karna dilaksanakan pada lembaga non formal seperti kursus, training, magang, dan sebagainya

d. Biaya yang dibutuhkan relatif kecil

Karena pelaksanaan pelatihan waktunya tidak lama dan bersifat sementara maka biaya yang dibutuhkan juga relatif kecil.

e. Tempat yang digunakan biasanya di lapangan praktek.

Tempat pelaksanaan pelatihan bagi pegawai adalah di lapangan seperti di laboratorium, dan ruang yang disediakan khusus untuk plaksanaan pelatihan.

Indikator pelatihan menurut Sedarmayanti (2007:165) adalah:

a. Materi yang diberikan

$\begin{array}{lcr}\begin{array}{l}\text { Secara garis } \\ \text { dikemukakan } \\ \text { pembelajaran }\end{array} & \text { bahwa } & \text { Mapat } \\ \text { (instructional }\end{array}$

materials) adalah pengetahuan, keterampilan, dan sikap yang harus dikuasai peserta pelatihan dalam rangka memenuhi standar kompetensi yang ditetapkan.

b. Komunikasi

Komunikasi ini merupakan kebutuhan yang paling mendasar manusia. Saat seseorang dengan orang lain berdekatan maka terjadi komunikasi secara verbal, namun jika mereka berada dalam jarak yang jauh mereka menggunakan beberapa cara untuk berkomunikasi. 
c. Motivasi

Suatu sugesti atau dorongan yang muncul karena diberikan oleh seseorang kepada orang lain atau dari diri sendiri, dorongan tersebut bermaksud agar orang tersebut menjadi orang yang lebih baik dari yang sebelumnya. Motivasi juga bisa diartikan sebagai sebuah alasan yang mendasari sebuah perbuatan yang dilakukan oleh seseorang.

d. Keterampilan teknis

Kemampuan untuk menggunakan peralatan-peralatan, prosedur, dan metode dari suatu bidang tertentu.

Sedangkan menurut Notoatmojo (2000:25) tujuan pelatihan bagi para pegawai adalah:

a. Mengembangkan aspirasi dan pemahaman, para pegawai tentang konsep, prinsip, metode, dan praktek serta pelaksanaan tugas dan kerja.

b. Mengubah perilaku dan kepercayaan serta menumbuhkan kesadaran pada masyarakat, khususnya para anggota pelatihan tentang arti penting atau manfaat pelatihan.

c. Mengembangkan rasa percaya diri, kemandirian dan kesetian diantara pegawai serta pemahaman tentang kewajiban, tugas, serta hak, termasuk hak-hak istimewa mereka.

d. Meningkatkan kompetisi para pegawai untuk memperbaiki manajemen dan kinerja.

e. Menjamin kesinambungan pemasokan kepemimpinan diberbagai tingkatan organisasi.

f. Mendorong dan menopang kebijaksanaan pemerintah.

Dalam pelaksanaan pengembangan sumber daya manusia ini perlu mempertimbangkan faktorfaktor baik dari dalam diri badan usaha atau organisasi itu sendiri maupun dari luar organisasi yang bersangkutan. Menurut Notoatmodjo (2000:18) Faktor-faktor yang mempengaruhi pengembangan sumber daya manusia adalah

1. Faktor Internal

Secara rinci faktor-faktor tersebut antara lain:

a. Misi dan Tujuan Organisasi

Setiap badan usaha mempunyai misi dan tujuan yang ingin dicapainya. Untuk mencapai tujuan ini diperlukan perencanaan yang baik, serta implementasi perencanaan tersebut secara tepat.

b. Strategi Pencapaian Tujuan Misi dan tujuan organisasi atau badan usaha mungkin mempunyai persamaan dengan organisasi lain, tetapi strategi untuk mencapai misi dan tujuan tersebut berbeda, oleh sebab itu setiap organisasi mempunyai strategi yang tertentu. Untuk itu maka diperlukan kemampuan pegawainya dalam memperkirakan dan mengantisipasi keadaan diluar yang dapat mempunyai dampak terhadap organisasi atau badan usahanya.

c. Sifat dan Jenis Kegiatan

Suatu organisasi adalah badan usaha sebagian besar melaksanakan kegiatan teknis, maka pola pengembangan sumber daya manusia akan berbeda dengan organisasi yang kegiatannya rutin dengan organisasi yang kegiatannya memerlukan inovasi dan kreatifitas.

d. Jenis teknologi yang digunakan Hal ini perlu diperhatikan dalam proses pengembangan sumber daya manusia akan berbeda dengan organisasi yang bersifat 
ilmiah. Demikian pula strategi dan program pengembangan sumber daya manusia disini diperlukan, baik untuk mempersiapkan tenaga guna menangani mengoperasikan teknologi itu, atau mungkin terjadinya otomatisasi kegiatan-kegiatan yang semula dilakukan oleh manusia.

2. Faktor Eksternal

Faktor-faktor tersebut antara lain:

a. Kebijaksanaan pemerintah Kebijaksanaan-kebijaksanaan pemerintah baik yang dikeluarkan melalui perundangan-undangan, peraturan-peraturan pemerintah, surat-surat keputusan menteri atau pejabat pemerintah dan sebagainya adalah merupakan arahan yang harus diperhitungkan oleh organisasi atau badan usaha.

b. Sosial-budaya masyarakat. Hal ini dapat dipahami karena suatu organisasi apapun didirikan untuk kepentingan masyarakat yang mempunyai latar belakang sosial budaya yang berbedabeda.

c. Perkembangan ilmu pengetahuan dan teknologi

Perkembangan ilmu pengetahuan dan teknologi diluar organisasi telah sedemikian pesatnya. Sudah tentu suatu organisasi yang baik harus mengikuti arus tersebut. Organisasi harus memilih teknologi yang tepat untuk organisasi. Untuk itu maka kemampuan pegawai organisasi harus diadaptasikan dengan kondisi tersebut.

Menurut Hasibuan (2002:94) prestasi kerja adalah suatu hasil kerja yang dicapai seseorang dalam melaksanakan tugas-tugas yang telah dibebankan kepadanya berdasarkan kecakapan, pengalaman, dan kesungguhan serta waktu. Menurut Rivai (2005:14) Prestasi kerja adalah hasil atau tingkat keberhasilan seseorang secara keseluruhan dalam periode tertentu didalam melaksankan tugas dibanding dengan berbagai kemungkinan, seperti standar hasil kerja target atau sasaran atau kriteria yang telah ditentukan terlebih dahulu dan telah disepakati bersama.

Menurut Notoatmodjo (2000:145) menyatakan bahwa prestasi kerja adalah pencapaian kerja oleh pegawai yang ingin memiliki peluang untuk mengembangkan kemampuan kerjanya sampai ketingkat maksimal. Dari definisi para ahli diatas yang dimaksud prestasi kerja adalah suatu hasil kerja yang dicapai seseorang dengan membandingkan hasil kerja yang telah dilakukan terdahulu dan yang dilakukan sekarang.

Indikator penilaian prestasi kerja pegawai menurut Hasibuan (2002:94):

a. Kerja sama

Penilai menilai kesediaan pegawai berprestasi dan bekerjasama dengan pegawai lain secara pertikal dan horizontal di dalam maupun di luar pekerjaan sehingga hasil pekerjaan semakin baik.

b. Tanggung jawab

Penilai menilai kesedian pegawai dalam mempertanggung jawabkan kebijaksanaan, pekerjaan,dan hasil kerjanya, sarana dan prasarana yang dipergunakannya serta perilaku kerjanya.

c. Kedisiplinan

Penilai menilai disiplin pegawai dalam memenuhi peraturanperaturan yang ada dan melakukan pekerjaannya sesuai dengan instruksi yang di berikan kepadanya.

d. Kejujuran

Penilai menilai kejujuran dalam melaksanakan tugas-tugasnya memenuhi perjanjian baik bagi 
dirinya sendiri maupun terhadap orang lain seperti kepada bawahannya.

Dari uraian di atas dampak faktor yang dapat digunakan untuk menilai tingkat prestasi kerja pegawai tidak akan sama untuk semua perusahaan,tetapi pada dasar nya apa yang di kemukakan merupakan faktor yang lazim digunakan dalam menilai prestasi kerja pegawai.

Penilaian prestasi kerja (performance appraisal) dalam rangka pengembangan sumber daya manusia adalah sangat penting artinya. Hal ini mengingat bahwa dalam kehidupan organisasi setiap orang sumber daya manusia dalam organisasi ingin mendapatkan penghargaan dan perlakuan yang adil dari pimpinan organisasi bersangkutan.

Dalam kehidupan suatu organisasi ada beberapa asumsi tentang perilaku manusia sebagai sumber daya manusia, yang mendasari pentingnya penilaian prestasi kerja. Asumsi-asumsi tersebut antara lain sebagai berikut:

a. Setiap orang ingin memiliki peluang untuk mengembangkan kemampuan kerjanya sampai tingkat yang maksimal.

b. Setiap orang ingin mendapatkan penghargaan apabila ia dinilai melaksanakan tugas dengan baik.

c. Setiap orang ingin mengetahui secara pasti tangga karier yang dinaikinya apabila dapat melaksanakan tugasnya dengan baik.

d. Setiap orang ingin mendapatkan perlakuan yang objektif dan penilaian dasar prestasi kerjanya.

e. Setiap orang bersedia menerima tanggung jawab yang lebih besar.

f. Setiap orang pada umumnya tidak hanya melakukan kegiatan yang sifatnya rutin tanpa informasi.
Manfaat penilaian prestasi kerja dalam suatu organisasi menurut Notoatmodjo (2000:134) antara lain sebagai berikut:

a. Peningkatan prestasi kerja

Dengan adanya penilaian, baik manajer maupun pegawai memperoleh umpan balik, dan mereka dapat memperbaiki pekerjaan mereka.

b. Kesempatan kerja yang adil

Dengan adanya penilaian kerja yang akurat menjamin setiap pegawai memperoleh kesempatan menempati posisi pekerjaan sesuai dengan kemampuannya.

c. Kebutuhan-kebutuhan pelatihan pengembangan

Melalui penilaian prestasi kerja akan dideteksikan pegawai-pegawai yang kemampuannya rendah, dan kemudian memungkinkan adanya program pelatihan untuk meningkatkan kemampuan mereka.

d. Penyesuaian kompensasi

Penilaian prestasi kerja dapat membantu para manajer untuk mengambil keputusan dalam menentukan perbaikan pemberian kompensasi,gaji, bonus, dan sebagainya.

e. Keputusan-keputusan promosi

Hasil penilaian prestasi kerja terhadap pegawai dapat digunakan untuk mengambil keputusan untuk mempromosikan pegawai yang berprestasi baik, dan promosi untuk pegawai yang berprestasi jelek.

f. Kesalahan-kesalahan desain pekerjaan

Hasil penilaian prestasi kerja dapat digunakan untuk menilai desain kerja. artinya hasil penilaian prestasi kerja ini dapat membantu mendiagnosis kesalahan-kesalahan kerja.

g. Penyimpangan-peryimpangan proses rekruitmen dan seleksi 
Penilain prestasi kerja dapat digunakan untuk menilaikan proses rekruitmen dan seleksi pegawai yang telah lalu.

Tujuan penilaian pretasi kerja pegawai adalah setiap penilaian hasil prestasi kerja pegawai harus benarbenar memiliki tujuan yang jelas, apa yang ingin dicapai. Menurut Martoyo (2000:95) tujuan yang ingin dicapai dengan penilaian tersebut dapat bermacam-macam antara lain untuk:

a. Mengidentifikasi para pegawai mana yang membutuhkan pendidikan dan pelatihan.

b. Menetapkan kenaikan gaji ataupun upah pegawai

c. Menetapkan

pemindahan

kemungkinan

dipromosikan jabatan yang lebih tinggi dan sebagainya.

Menurut Hasibuan (2002:96-99), metode penilaian prestasi kerja pegawai pada dasarnya di kelompokan menjadi 2 macam, yakni sebagai berikut:

1) Tradisional Metode

Metode untuk menilai prestasi kerja pegawai dan diterapkan secara tidak sistematis. Yang termasuk kedalam metode tradisional adalah

\section{a. Rating Scale}

Yaitu penilaian prestasi kerja yang biasanya diisi oleh atasan langsung dengan menandai tanggapan yang paling sesuai untuk setiap dimensi pelaksanaan kerja.

b. Employee comparation

Metode ini merupakan metode penilaian yang di lakukan dengan cara membandingkan antara seorang pekerja dengan pekerja lainnya.

c. Check list

Metode ini adalah untuk mengurangi beban penilai, metode ini bisa memberikan suatu gambaran prestasi kerja secara akurat, bila daftar penilai berisi item-item yang memadai.

d. Freeform essay

Dengan metode ini seorang penilai diharuskan membuat karangan yang berkenan dengan orang/pegawai yang sedang dinilainya.

e. Critical incident

Dengan metode ini penilai harus mencatat semua kejadian mengenai tingkah laku bawahannya sehari-hari yang kemudian dimasukan kedalam buku catatan khusus yang terdiri dari berbagai macam katagori tingkah laku bawahannya.

2) Metode modern

Metode ini merupakan perkembangan dari metode tradisional dalam menilai prestasi kerja pegawai. Yang termasuk metode modern adalah:

1) Assesment centre

metode ini biasanya dilakukan dengan pembentukan tim penilai khusus.

2) Management by objective

Metode ini pegawai langsung diikut sertakan dalam perumusan dan pemutusan persoalan dengan memperhatikan kemampuan bawahan dalam menentukan sasaranya masing-masing yang ditekankan pada pencapaian sasaran perusahaan.

Faktor-faktor yang dapat mempengaruhi prestasi kerja pegawai menurut Handoko, (2001:266) antara lain:

1. Gaji yang cukup

Gaji yang cukup disini adalah jumlah yang diberikan atau dibayar tanpa menimbulkan kerugian instansi 
tersebut dan mampu memberikan semangat kerja pada tenaga kerja.

2. Tempat pegawai pada posisi yang tepat

Ketidaktepatan fungsi pegawai akan meyebabkan jalannya pekerjaan kurang lancar dan tidak akan memperoleh hasil yang baik.

3. Sesekali perlu menciptakan suasana yang santai

Suasana yang rutin menimbulkan kebosanan dan Ketegangan bagi pegawai, untuk menghindarkan hal itu maka instansi harus menciptakan suasana yang nyaman.

4. Beri kesempatan mereka maju

Semangat kerja pegawai akan timbul dan meningkat bila pegawai yang berprestasi diberi penghargaan.

5. Perasaan aman

Untuk menghadapi masa depan perlu diperhatikan, seperti menyisihkan atau menyimpan sebagian pendapatan untuk ditabung.

6. Sesekali pegawai perlu diajak berunding

Dengan mengikut sertakan mereka maka perasaan bertanggung jawab akan timbul sehingga mereka dapat melaksanakan kebijakan baru tersebut akan lebih baik.

7. Fasilitas yang menyenangkan

Setiap perusahaan bilamana memungkinkan hendaknya menyediakan fasilitas yang menyenangkan seperti cafetaria dan tempat olahraga.

\section{B. Metodologi Penelitian}

Model penelitian ini adalah pelatihan $\left(\mathrm{X}_{1}\right)$ sebagai variabel bebas, dan prestasi kerja $(Y)$ sebagai variabel terikat. Berikut gambar model dalam penelitian ini :

\section{Gambar 1 Model Penelitian}

\begin{tabular}{|c|c|}
\hline PELATIHAN (X) & PRESTASI KERJA (Y) \\
\hline$\downarrow$ & $\downarrow$ \\
\hline $\begin{array}{l}\text { Indikator } \\
\text { a. Materi yang di berikan } \\
\text { b. pengetahuan } \\
\text { c. motivasi } \\
\text { d. keterampilan teknis }\end{array}$ & $\begin{array}{l}\text { Indikator } \\
\text { a. Kerja sama } \\
\text { b. Tanggung Jawab } \\
\text { c. Kedisiplinan } \\
\text { d. Kejujuran }\end{array}$ \\
\hline
\end{tabular}

Dari gambar diatas, dapat diterangkan bahwa ada pengaruh pelatihan $\left(X_{1}\right)$ terhadap prestasi kerja pegawai $(Y)$. Hal ini diperkuat oleh penelitian Marlia (2007), yang menemukan bahwa ada pengaruh positif yang signifikan pelatihan terhadap prestasi kerja pegawai. Menurut Sugiyono (2005:64) hipotesis merupakan jawaban sementara terhadap rumusan masalah penelitian, di mana rumusan masalah penelitian dinyatakan dalam bentuk kalimat pertanyaan. Dikatakan sementara, karena jawaban yang diberikan baru didasarkan pada teori yang relevan, belum didasarkan pada fakta-fakta empiris yang diperoleh melalui pengumpulan data. Hipotesis dalam penelitian ini adalah:

Ho: diduga tidak ada pengaruh positif yang signifikan pelatihan terhadap prestasi kerja pegawai pada CV. Ayoeb Brothers. 
Ha: diduga ada pengaruh positif yang signifikan pelatihan terhadap prestasi kerja pegawai pada CV. Ayoeb Brothers.

Populasi dalam penelitian ini adalah seluruh pegawai CV. Ayoeb Brothers sebanyak 34 orang. sampel yang akan diteliti adalah semuanya yaitu 34 orang. Metode Penelitian yang diterapkan adalah metode kausal komparatif yaitu penyelidikan empiris yang sistematis dimana ilmuwan tidak mengendalikan variabel bebas secara langsung karena eksistensi variabel tersebut sudah terjadi. Penulis mengumpulkan data sesuai dengan yang dikemukakan Husein (2009:49) ada beberapa cara teknik pengumpulan data yaitu: 1) Teknik Kuisioner, merupakan pengumpulan data dengan cara melakukan penyebaran data kuesioner (daftar pertanyaan), 2) Teknik Dokumentasi, merupakan pengumpulan melalui dokumen-dokumen dan laporan yang ada di perusahaan dan memiliki elevansi dengan penelitian.

\section{Pembahasan}

Priyatno (2010:90) mengatakan uji validitas adalah ketepatan atau kecermatan suatu instrumen dalam mengukur apa yang ingin diukur. Uji validitas digunakan untuk mengukur ketepatan butir kuisioner dalam kuisioner. Output uji validitas memberikan hasil korelasi antara skor butir-butir kuisioner variabel penelitian dengan skor total variabel penelitian. Nilai yang diperoleh dari uji validitas kemudian dibandingkan dengan nilai $r$ tabel.

Tabel 1

Hasil Uji Validitas Variabel Pelatihan

\begin{tabular}{|c|c|c|c|c|}
\hline $\begin{array}{c}\text { Butir } \\
\text { Pertanyaan }\end{array}$ & $\mathbf{r}_{\text {hitung }}$ & $\mathbf{r}_{\text {tabel }} \mathbf{( \alpha = 5 \% )}$ & Kriteria & Kesimpulan \\
\hline 1 & 0,469 & 0,339 & $r_{\text {hitung }}>r_{\text {tabel }}$ & Valid \\
2 & 0,345 & 0,339 & $r_{\text {hitung }}>r_{\text {tabel }}$ & Valid \\
3 & 0,674 & 0,339 & $r_{\text {hitung }}>r_{\text {tabel }}$ & Valid \\
4 & 0,739 & 0,339 & $r_{\text {hitung }}>r_{\text {tabel }}$ & Valid \\
5 & 0,750 & 0,339 & $r_{\text {hitung }}>r_{\text {tabel }}$ & Valid \\
6 & 0,701 & 0,339 & $r_{\text {hitung }}>r_{\text {tabel }}$ & Valid \\
7 & 0,598 & 0,339 & $r_{\text {hitung }}>r_{\text {tabel }}$ & Valid \\
8 & 0,596 & 0,339 & $r_{\text {hitung }}>r_{\text {tabel }}$ & Valid \\
9 & 0,520 & 0,339 & $r_{\text {hitung }}>r_{\text {tabel }}$ & Valid \\
10 & 0,539 & 0,339 & $r_{\text {hitung }}>r_{\text {tabel }}$ & Valid \\
\hline
\end{tabular}

Sumber : Data primer yang diolah, 2016

Berdasarkan tabel 1 terlihat bahwa semua butir pertanyaan pada variabel pelatihan yang menunjukan nilai rhitung lebih besar dari pada rtabel. Dengan demikian dapat disimpulkan bahwa semua butir pertanyaan yang dijadikan sebagai indikator terhadap variabel pelatihan telah valid atau tepat untuk dijadikan sebagai alat ukur dalam penelitian ini. 
Tabel 2

Hasil Uji Validitas Variabel Prestasi Kerja

\begin{tabular}{|c|c|c|c|c|}
\hline $\begin{array}{c}\text { Butir } \\
\text { pertanyaan }\end{array}$ & $\mathbf{r}_{\text {hitung }}$ & $\begin{array}{c}\mathbf{r}_{\text {tabel }} \\
\mathbf{( \alpha = 5 \% )}\end{array}$ & Kriteria & Kesimpulan \\
\hline 1 & 0,513 & 0,339 & $r_{\text {hitung }}>r_{\text {tabel }}$ & Valid \\
2 & 0,380 & 0,339 & $r_{\text {hitung }}>r_{\text {tabel }}$ & Valid \\
3 & 0,532 & 0,339 & $r_{\text {hitung }}>r_{\text {tabel }}$ & Valid \\
4 & 0,388 & 0,339 & $r_{\text {hitung }}>r_{\text {tabel }}$ & Valid \\
5 & 0,522 & 0,339 & $r_{\text {hitung }}>r_{\text {tabel }}$ & Valid \\
6 & 0,499 & 0,339 & $r_{\text {hitung }}>r_{\text {tabel }}$ & Valid \\
7 & 0,563 & 0,339 & $r_{\text {hitung }}>r_{\text {tabel }}$ & Valid \\
8 & 0,347 & 0,339 & $r_{\text {hitung }}>r_{\text {tabel }}$ & Valid \\
9 & 0,528 & 0,339 & $r_{\text {hitung }}>r_{\text {tabel }}$ & Valid \\
10 & 0,412 & 0,339 & $r_{\text {hitung }}>r_{\text {tabel }}$ & Valid \\
\hline
\end{tabular}

Sumber : Data primer yang diolah, 2016

Berdasarkan tabel 2 diatas terlihat bahwa semua butir pertanyaan pada variabel prestasi kerja

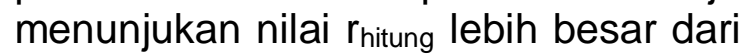
pada $r_{\text {tabel. }}$ Dengan demikian dapat disimpulkan bahwa semua butir kuisioner yang dijadikan sebagai indikator terhadap variabel prestasi kerja telah valid atau tepat untuk dijadikan sebagai alat ukur dalam penelitian ini dan selanjutnya.

Dalam melakukan pengujian reliabilitas terhadap item-item pertanyaan variabel Pelatihan $(X)$ dan variabel Prestasi Kerja (Y) menggunakan Alpha Cronbach's menurut sekaran dalam Priyatno (2010:98) jika nilai Cronbach Alpha item > dari 0,6 maka reliabel, sedangkan jika nilai Cronbach Alpha item $<0,6$ maka tidak reliabel.

Tabel 3

Hasil Uji Reliabilitas Variabel Pelatihan

\begin{tabular}{|c|c|}
\hline Cronbach's Alpha & N of Items \\
\hline .780 & 10 \\
\hline
\end{tabular}

Sumber : Data primer yang diolah, 2016

Berdasarkan tabel 3 menunjukan bahwa nilai Cronbach Alpha sebesar 0,780 Karena nilai reliabilitas lebih besar dari 0,6 maka dari 10 butir pertanyaan yang dijadikan sebagai indikator pada variabel pelatihan sudah reliabel.

Tabel 4

Hasil Uji Reliabilitas Variabel Prestasi Kerja

\begin{tabular}{|c|c|}
\hline Cronbach's Alpha & N of Items \\
\hline .601 & 10 \\
\hline
\end{tabular}

Sumber : Data primer yang diolah, 2016

Berdasarkan tabel 4 menunjukan bahwa nilai Cronbach Alpha sebesar 0,601 Karena nilai reliabilitas lebih besar dari 0,6 maka dari 10 pertanyaan yang dijadikan sebagai indikator pada variabel prestasi kerja sudah reliabel. 
Tabel 5

Hasil Uji Regresi Linier Sederhana

\begin{tabular}{|c|c|c|c|c|c|}
\hline \multirow[b]{2}{*}{ Variabel } & \multicolumn{2}{|c|}{$\begin{array}{l}\text { Unstandardized } \\
\text { Coefficients }\end{array}$} & \multirow{2}{*}{\begin{tabular}{|l}
$\begin{array}{l}\text { Standardized } \\
\text { Coefficients }\end{array}$ \\
Beta
\end{tabular}} & \multirow[b]{2}{*}{$\mathrm{T}$} & \multirow[b]{2}{*}{ Sig. } \\
\hline & $B$ & Std. Error & & & \\
\hline (Constant) & 31.624 & 4.414 & & 4.734 & .000 \\
\hline X Pelatihar & .258 & .103 & .540 & 3.007 & .000 \\
\hline
\end{tabular}

a. Dependent Variable: $Y$

Sumber : Data primer yang diolah, 2016

Berdasarkan tabel 5 tersebut diatas diperoleh persamaan sebagai berikut: $Y=31,624+0,258 X$. Konstata sebesar 31.624 artinya apabila pelatihan $(X)$ nilainya adalah 0 maka prestasi kerja $(\mathrm{Y})$ sebesar 31.624
Sedangkan koefisien regresi variabel pelatihan $(X)$ sebesar 0,258 artinya jika pelatihan mengalami kenaikan satu satuan maka prestasi kerja (Y) mengalami peningkatan 0,258.

Tabel 6

Hasil Uji Koefisien Korelasi

\begin{tabular}{|l|l|l|l|l|}
\hline Model & $R$ & $R$ Square & $\begin{array}{l}\text { Adjusted } \\
\text { Square }\end{array}$ & $\begin{array}{l}\text { Std. Error of } \\
\text { the Estimate }\end{array}$ \\
\hline 1 & $.402^{\mathrm{a}}$ & .162 & .279 & 3.406 \\
\hline
\end{tabular}

a. Predictors: (Constant), $\mathrm{X}$

Sumber : Data primer diolah, 2016

Tabel 7

Intrepretasi Koefisien Korelasi

\begin{tabular}{|c|c|}
\hline Interval koefisien & Tingkat hubungan \\
\hline $0,00-0,199$ & Sangat rendah \\
$0,20-0,399$ & Rendah \\
$0,40-0,599$ & Sedang \\
$0,60-0,799$ & Kuat \\
$0,80-0,1000$ & Sangat kuat \\
\hline
\end{tabular}

Sumber : Sugiyono, (2005:251)

Berdasarkan tabel 6 dan tabel 7 diperoleh koefisien korelasi sebesar 0,402 . Hasil tersebut dapat diartikan bahwa hubungan korelasi antara variabel pelatihan dengan prestasi kerja adalah positif dengan tingkat hubungan sedang.

Tabel 8

Koefisien Determinasi

\begin{tabular}{|l|l|l|l|l|}
\hline Model & $\mathrm{R}$ & $\mathrm{R}$ Square & $\begin{array}{l}\text { Adjusted } \\
\text { Square }\end{array}$ & $\begin{array}{l}\mathrm{R} \\
\text { Std. Error of } \\
\text { the Estimate }\end{array}$ \\
\hline 1 & $.402^{\mathrm{a}}$ & .162 & .279 & 3.406 \\
\hline
\end{tabular}

Sumber : Data primer diolah, 2016 
Berdasarkan tabel 8 di atas dapat kita ketahui bahwa nilai $R$ Square sebesar 0,162 yang berarti bahwa variabel pelatihan dapat menjelaskan prestasi kerja pegawai sebesar 16,2\% atau dengan kata lain kontribusi pelatihan terhadap prestasi kerja pegawai CV. Ayoeb Brothers di Palembang sebesar $16,2 \%$ sedangkan sisanya sebesar $83,8 \%$ dipengaruhi oleh variabel lain yang tidak diteliti dalam penelitian.

\section{Tabel 9}

\section{Hasil Uji T}

Coefficients $^{\mathrm{a}}$

\begin{tabular}{|ll|r|r|r|r|r|}
\hline \multirow{2}{*}{ Model } & \multicolumn{2}{|c|}{$\begin{array}{c}\text { Unstandardized } \\
\text { Coefficients }\end{array}$} & \multicolumn{2}{c|}{$\begin{array}{c}\text { Standardized } \\
\text { Coefficients }\end{array}$} & & \\
\cline { 2 - 5 } & \multicolumn{1}{|c|}{$\mathrm{B}$} & Std. Error & \multicolumn{1}{|c|}{ Beta } & \multicolumn{1}{c|}{ T } & Sig. \\
\hline 1 & (Constant) & 31.624 & 4.414 & & 3.734 & .000 \\
& $\mathrm{X}$ & .258 & .103 & .540 & 3.007 & .000 \\
\hline
\end{tabular}

a. Dependent Variable: $Y$

Sumber : Data primer diolah, 2016

Untuk uji hipotesis nilai t-hitung $>$ t-tabel, $(3,007>2,037)$. Jadi Ho ditolak Ha diterima, maka dapat disimpulkan bahwa ada pengaruh positif yang signifikan pelatihan terhadap prestasi kerja pegawai CV. Ayoeb Brothers di Palembang.

\section{Kesimpulan dan Saran}

Kesimpulan dalam penelitian ini berdasarkan dari hasil pembahasan yaitu :

1. Berdasarkan hasil perhitungan dengan menggunakan SPSS for windows (Statistical Product and Service Solution) hasil perhitungan regresi linier sederhana sebagai berikut: $\mathrm{Y}=31,624+0,258 \mathrm{X}$ dan hasil output angka koefisien korelasi sederhana $(r)$ sebesar 0,402. Dan dari hasil uji hipotesis nilai thitung > t-tabel $(3,007>2,037)$ jadi Ho ditolak dan Ha diterima, yaitu ada pengaruh positif yang signifikan pelatihan terhadap prestasi kerja pegawai CV. Ayoeb Brothers di Palembang.
2. Koefisien determinasi (r2) sebesar $\quad 0,162 \quad(16,2 \%)$ menunjukkan bahwa pelatihan memberi sumbangan pengaruh terhadap prestasi kerja sebesar $16,2 \%$ selebihnya sebesar $83,8 \%$ dipengaruhi oleh variabel lain yang tidak diteliti dalam penelitian ini.

Saran yang dapat diberikan berkaitan dengan temuan yang telah diperoleh adalah laksanakan program pelatihan bagi pegawai, agar prestasi kerja pegawai dapat semakin meningkat. Melalui pelatihan diharapkan akan dapat meningkatkan ketrampilan dan pengetahuan yang dimiliki oleh pegawai, sehingga diharapkan semua pekerjaan dapat dilaksanakan dengan lebih efektif dan efisien serta tingkat kesalahan yang dilakukan pegawai dapat menjadi seminimal mungkin dan mutu dan kualitas kerja dapat ditingkatkan. 


\section{DAFTAR PUSTAKA}

Gomes, Faustino cardoso, 2003. Manajemen Sumber Daya Manusia. Yogyakarta: Andi.

Handoko, Hani T. 2001. Manajemen. Yogyakarta: BPFE.

Husein, Umar. 2009 Metode Penelitian Aplikasi dalam Pemasaran. Jakarta: PT. Gramedia Pustaka Utama.

Marlia, Elfina. 2007. Pengaruh Program Pendidikan dan Pelatihan Terhadap Prestasi Kerja Karyawan Pada PT. Inti (Persero Bandung. Skripsi. Universitas Widyatama.

Hasibuan. Malayu SP. 2002. Manajemen Sumber Saya Manusia. Jakarta: PT. Bumi Aksara.

Priyatno. Duwi. 2010. 5 Jam Belajar Olah data dengan SPSS. Yogyakarta: Andi.

Rivai, Veithzal. 2005. Kepemimpinan dan Prilaku Organisasi, Jakarta: PT. Rajagrafindo Persada.

Sedarmayanti, 2007. Manajemen Sumber Daya Manusia. Bandung: Repika Aditama.

Sihotang. 2007. Manajemen Sumber Daya Manusia. Jakarta: PT.Pradya Paramita.

Notoatmodjo, Soekidjo. 2000. Pengembangan Sumber Daya Manusia. Jakarta: PT. Rineka Cipta.

Sugiyono. 2005. Metode Penelitian Bisnis. Bandung: Penerbit Alfabeta.
Martoyo, Susilo. 2000. Manajemen Sumber Daya Yogyakarta: BPEE. Manusia. 